\title{
Prediksi Permintaan Kargo pada Cargo Service Center Tangerang City Menggunakan Metode Gated Recurrent Unit
}

\author{
Rifky Ahmad Saputra*1, Yufis Azhar², Vinna Rahmayanti ${ }^{3}$ \\ 1,2,3Teknik Informatika/Universitas Muhammadiyah Malang \\ rifkyahmadsaputra@gmail.com ${ }^{* 1}$,yufis.az@gmail.com ${ }^{2}$, vinna.nastiti@gmail.com ${ }^{3}$
}

\begin{abstract}
Abstrak
Pada saat ini persaingan bisnis dalam bidang layanan kargo khususnya di Indonesia semakin ketat. Terdapat beberapa perusahaan layanan kargo di Indonesia, salah satunya yaitu Cargo Service Center Tangerang City. Untuk mengantisipasi persaingan bisnis tersebut, Cargo Service Center Tangerang City harus dapat menentukan strategi manajemen usaha, baik dalam jangka menengah maupun jangka panjang. Salah satunya hal yang dapat dilakukan yaitu prediksi permintaan kargo. Pada Cargo Service Center Tangerang City terdapat data transaksi kargo mulai dari Januari 2016 hingga Septermber 2019, oleh karena itu dilakukanlah penelitian yaitu mengimplementasikan metode Gated Recurrent Unit untuk melakukan prediksi permintaan kargo. metode Gated Recurrent Unit merupakan model pengembangan dari Recurrent Neural Network yang biasa digunakan untuk melakukan prediksi pada data sekuens. Pengujian model prediksi dalam penelitian ini dilakukan dengan mencari nilai Root Mean Square Error terkecil dari beberapa percobaan. Hasil dari penelitian ini menunjukkan bahwa model cukup baik dalam melakukan prediksi permintaan kargo, namun terdapat beberapa hasil prediksi metode Gated Recurrent Unit yang masih belum maksimal mendekati nilai aktual misalnya pada nilai aktual yang berada di titik puncak.
\end{abstract}

Kata Kunci: Kargo, Prediksi, Deep Learning, Recurrent Neural Network, Gated Recurrent Unit

\section{Abstract}

At this time, business competition in the field of cargo shipping especially in Indonesia is getting tougher. There are some cargo service in Indonesia, one of them is Cargo Service Center Tangerang City. To anticipate that business competition, Cargo Service Center Tangerang City must be able to determine business management strategies in the medium and long term. One of the things that can done is predicting cargo demand. At Cargo Service Center Tangerang City, there are cargo transaction data from January 2016 to September 2019, therefore conduct research study that is implementing Gated Recurrent Unit method for predict cargo demand at Cargo Service Center Tangerang City. Gated Recurrent Unit is a development model of the Recurrent Neural Network that is commonly used to make predictions on sequence data. Testing prediction model in this research is conduct by finding the smallest Root Mean Square Error value from several experiments. The results of this research indicate that the model is quite good in predicting cargo demand, but there are some Gated Recurrent Unit prediction results that are still not maximally close to the actual value, for example at the actual value in the peak point.

Keywords: Cargo, Prediction, Deep Learning, Recurrent Neural Network, Gated Recurrent Unit

\section{Pendahuluan}

Permintaan kargo pada saat ini mengalami perkembangan yang cukup pesat di Indonesia, hal ini dikarenakan dengan pertumbuhan sosial ekonomi serta permintaan konsumen yang selalu meningkat. Kargo dapat didefinisikan sebagai semua barang yang dikirim melalui udara, darat maupun laut yang dilengkapi oleh dokumen pengangkutan (Air Way Bill) antar wilayah atau kota di dalam negeri maupun antarnegara [1] . Terdapat beberapa perusahaan layanan kargo di Indonesia, salah satunya yaitu CSC Tangerang City. CSC Tangerang City merupakan layanan kargo udara resmi dari Garuda yang berada pada Tangerang di Jalan Palem Raja Raya Selatan, Karawaci, Tangerang. CSC ini bertujuan sebagai tempat drop dan pick-up point barang, sehingga memudahkan pelanggan yang ingin mengirimkan barangnya tanpa perlu lagi harus datang ke bandara. 
Pada saat ini persaingan bisnis dalam bidang layanan kargo khususnya di Indonesia semakin ketat, salah satunya diakibatkan oleh perusahaan layanan kargo yang bertambah banyak dikarenakan pertumbuhan sosial ekonomi dan permintaan konsumen untuk kargo mengalami peningkatan. Dalam jangka panjang perusahaan khususnya CSC Tangerang City harus dapat meningkatkan dan memantapkan posisi usahanya di tengah-tengah persaingan bisnis yang semakin ketat dan kompleks. Untuk mengantisipasi hal itu, CSC Tangerang City harus dapat menentukan strategi manajemen usaha, baik dalam jangka menengah maupun jangka panjang. Salah satu yang dapat dilakukan adalah prediksi permintaan kargo pada perusahaan tersebut menggunakan data-data transaksi yang telah direkap setiap harinya.

Pada CSC Tangerang City terdapat data transaksi kargo mulai dari Januari 2016 hingga Septermber 2019, oleh karena itu dilakukanlah penelitian untuk prediksi permintaan kargo pada CSC Tangerang City dari data-data yang telah tersedia. Prediksi dilakukan dengan mengimplementasikan model Deep Learning, yaitu menggunakan metode Gated Recurrent Unit (GRU). Metode GRU-NN merupakan metode perkembangan dari metode Recurrent Neural Network yang dapat melakukan prediksi pada data time-series (deret waktu).

Pada penelitian Baxter, dkk [2] melakukan prediksi permintaan kargo udara ekspor Australia tahunan dengan menggunakan metode Artificial Neural Network dan menghasilkan nilai Root Mean Square Error (RMSE) sebesar $1.3 \times 10^{\wedge} 4$. Pada penelitian Uyar, dkk [3] melakukan prediksi tarif permintaan angkutan kargo dengan menggunakan metode Fuzzy Recurrent Neural Network dengan menghasilkan nilai MAPE 14,96\%. Sedangkan pada penelitian Fu, dkk [4] yaitu menggunakan metode ARIMA, LSTM dan GRU untuk prediksi arus lalu lintas. Hasil yang didapat adalah bahwa metode GRU lebih unggul nilai akurasinya dibandingkan dari metode lainnya. Pada penelitian yang dilakukan Aji [5] melakukan prediksi pada data time series (deret waktu) yaitu melakukan prediksi harga bitcoin dengan menggunakan metode GRU. Penelitian tersebut menghasilkan nilai MAPE sebesar 5,43\%.

Penelitian ini mengusulkan penggunaan metode Gated Recurrent Unit (GRU) untuk melakukan prediksi permintaan kargo. Metode GRU diperkenalkan pada tahun 2014 oleh Cho, dkk [6]. GRU merupakan metode pengembangan dari Recurrent Neural Network (RNN) yang bertujuan untuk membuat setiap recurrent unit bisa dapat menangkap hubungan (dependensi) dalam skala waktu yang berbeda-beda secara adaptif [7]. Menurut Rahman,dkk [8] menyatakan bahwa metode GRU memiliki lebih sedikit parameter daaripada Long Short-Term Memory (LSTM) sehingga komputasinya lebih sederhana dan waktu yang dibutuhkan lebih sedikit. Serta akurasi yang didapat setara bahkan bisa lebih dari metode LSTM, tergantung dari data dan studi kasusnya. Berdasarkan hasil yang didapat pada penelitian Fu,dkk [4] menunjukkan bahwa metode GRU memiliki nilai kesalahan (error) yang lebih kecil dibandingkan metode LSTM dan ARIMA.

Berdasarkan dari penjelasan sebelumnya, maka dilakukan penelitian tentang prediksi permintaan kargo pada perusahan CSC Tangerang City dengan menggunakan metode Gated Recurrent Unit (GRU). Data yang digunakan untuk penelitian ini adalah data transaksi kargo CSC Tangerang City dari Januari 2016 hingga September 2019. Pada penelitian ini diharapkan dapat mengimplementasikan metode GRU dalam melakukan prediksi permintaan kargo pada CSC Tangerang City dan menghasilkan nilai kesalahan (error) yang kecil.

\section{Metode Penelitian}

\subsection{Pengumpulan Data}

Data yang digunakan pada penelitian ini adalah data mentah transaksi kargo pada perusahaan Cargo Service Center Tangerang City mulai dari Januari 2016 hingga September 2019. Data mentah tersebut berisikan kumpulan transaksi pengiriman kargo dalam perhari yang direkap tiap bulan.

\subsection{Preprocessing Data}

Preprocessing data adalah sebuah proses yang dilakukan untuk mempersiapkan data mentah yang telah dikumpulkan agar menjadi data yang berkualitas. Pada preprocessing data terdapat beberapa tahap yang dilakukan, tahap tersebut dijelaskan sebagai berikut.

\subsubsection{Merubah Format Data}

Data yang telah dikumpulkan akan dirubah format datanya dari format data pertransaksi menjadi perhari dengan cara melakukan subtotal pada transaksi (data numerik) berdasarkan

REPOSITOR, Vol. 2, No. 8, Agustus 2020: 1113-1122 
tanggalnya. Setelah itu, melakukan penyamaan format tanggal karena pada data mentah tersebut berisikan format tanggal yang berbeda-beda (tidak konsisten). Setelah data telah diubah formatnya, maka dipilih beberapa fitur yang akan digunakan dalam melakukan prediksi permintaan kargo.

\subsubsection{Mengatasi Data Outlier}

Pada tahap ini, dalam menentukkan suatu data merupakan data noise (outlier) atau tidak dapat dilakukan dengan menggunakan Boxplot. Boxplot merupakan ringkasan distribusi sampel yang disajikan secara grafis yang dapat menggambarkan distribusi data, ukuran tendensi sentral dan ukuran penyebaran. Boxplot juga dapat menunjukkan ada tidaknya nilai outlier dari data tersebut.

\subsubsection{Transformasi Logaritma Natural}

Setelah data bersih dari outlier, dilakukan transformasi logaritma natural untuk menstabilkan dan memperkecil nilai variansi dari data tersebut. Dalam melakukan transformasi logaritma natural pada data, dapat dilakukan dengan Persamaan 1.

$$
y^{\prime}=\ln (y)
$$

\subsubsection{Normalisasi Min-Max}

Setelah melakukan transformasi, dilanjutkan dengan melakukan normalisasi data dengan menggunakan metode normalisasi min-max. Metode min-max adalah metode normalisasi dengan melakukan transformasi linier terhadap data asli, seperti pada Persamaan 2 [9].

$$
x^{\prime}=\frac{x-\min (x)}{\max (X)-\min (x)}
$$

\subsection{Prediksi Menggunakan Metode Gated Recurrent Unit}

Pada tahap ini melakukan prediksi dari dataset transaksi yang telah di preprocessing dengan menggunakan metode Gated Recurrent Unit (GRU). GRU merupakan metode pengembangan dari Recurrent Neural Network (RNN) yang bertujuan untuk membuat setiap recurrent unit bisa dapat menangkap hubungan (dependensi) dalam skala waktu yang berbedabeda secara adaptif. Secara analogi, metode GRU menggunakan beberapa informasi pada masa lalu (sebelumnya) yang relevan untuk dapat membuat keputusan sekarang [6]. Ilustrasi dari metode GRU dapat dilihat pada Gambar 1.

\section{Gated recurrent unit (GRU)}

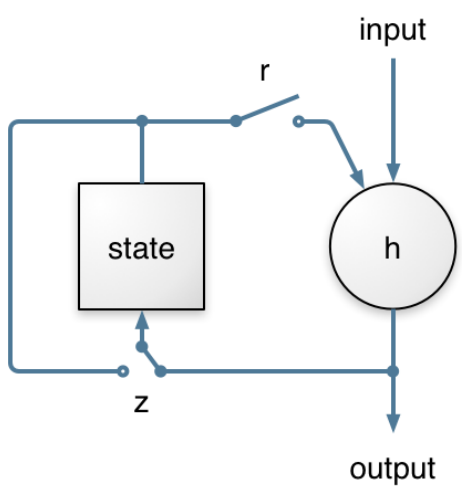

Gambar 1. Ilustrasi dari Metode GRU

Pada Gambar 1, merupakan ilustrasi dari metode GRU. Pada Metode GRU terdapat dua gerbang yaitu reset gate ' $r$ ' dan update gate ' $z$ ' yang digunakan untuk membentuk hidden state ' $h$ '. Update gate digunakan untuk menentukkan berapa banyak informasi masa lalu (sebelumnya) yang harus tetap disimpan. Sedangkan reset gate digunakan untuk memutuskan berapa banyak informasi masa lalu untuk dihapus dan menentukkan bagaimana menggabungkan input baru 
dengan informasi masa lalu (sebelumnya) [7]. Persamaan 3, Persamaan 4, dan Persamaan 5 berikut merupakan rumus-rumus yang terdapat pada metode GRU.

1. Update Gate

$$
z_{t}=\sigma_{g}\left(W_{z} x_{t}+U_{z} h_{t-1}+b_{z}\right)
$$

\section{Reset Gate}

$$
r_{t}=\sigma_{g}\left(W_{r} x_{t}+U_{r} h_{t-1}+b_{r}\right)
$$

3. Hidden State

$$
h_{t}=\left(1-z_{t}\right) \circ h_{t-1}+z_{t} \circ \sigma_{h}\left(W_{h} x_{i}+U_{h}\left(r_{t} \circ h_{t-1}\right)+b_{h}\right)
$$

\subsection{Pengujian dan Evaluasi Model Prediksi}

Setiap model prediksi yang telah dibuat, harus dilakukan pengujian dan evaluasi hasil prediksinya untuk mengetahui performa dari model prediksi tersebut. Dalam pengujian model prediksi, melakukan beberapa percobaan dengan nilai parameter yang berbeda-beda untuk menghasilkan hyperparameter terbaik untuk model prediksi. Dalam mengukur performa model prediksi, digunakan metode perhitungan Root Mean Square Error (RMSE) yang merupakan nilai akar dari nilai rata-rata error yang telah dikuadratkan. Nilai RMSE rendah menunjukkan bahwa variasi nilai hasil prediksi (output) mendekati variasi nilai sebenarnya (target) [10]. Persamaan 6 berikut merupakan rumus dari RMSE.

$$
R M S E=\sqrt{\frac{1}{n} \sum_{i=1}^{n}\left(y_{i}-\widehat{y}_{l}\right)^{2}}
$$

\section{Hasil Penelitian dan Pembahasan}

Implementasi dilakukan untuk memastikan sistem dapat berjalan sesuai dengan yang diharapkan. Implementasi dimulai dengan melakukan preprocessing data agar dapat digunakan, setelah itu mengimplementasikan arsitektur metode Gated Recurrent Unit untuk membuat model prediksi dan diakhiri dengan melakukan pengujian untuk mencari tahu hyperparameter terbaik berdasarkan hasil evaluasi dari nilai Root Means Square Error (RMSE) model tersebut.

\subsection{Pengujian Penentuan Learning Rate}

Learning Rate adalah nilai koreksi pembaharuan bobot dalam model prediksi, learning rate merupakan salah satu hyperparameter yang diujikan dalam penelitian ini. Pada pengujian ini, penentuan nilai learning rate terbaik ditentukkan berdasarkan grafik model loss yang tidak mengalami fluktuasi signifikan, tidak terjadi overfitting pada data validasi dan menghasilkan nilai validasi loss yang paling kecil. Pengujian learning rate yang akan diujikan adalah $0.1,0.01$ dan 0.001 . Berikut merupakan grafik model loss hasil pengujian yang dilakukan, dapat dilihat pada Gambar 2, Gambar 3, dan Ganbar 4.

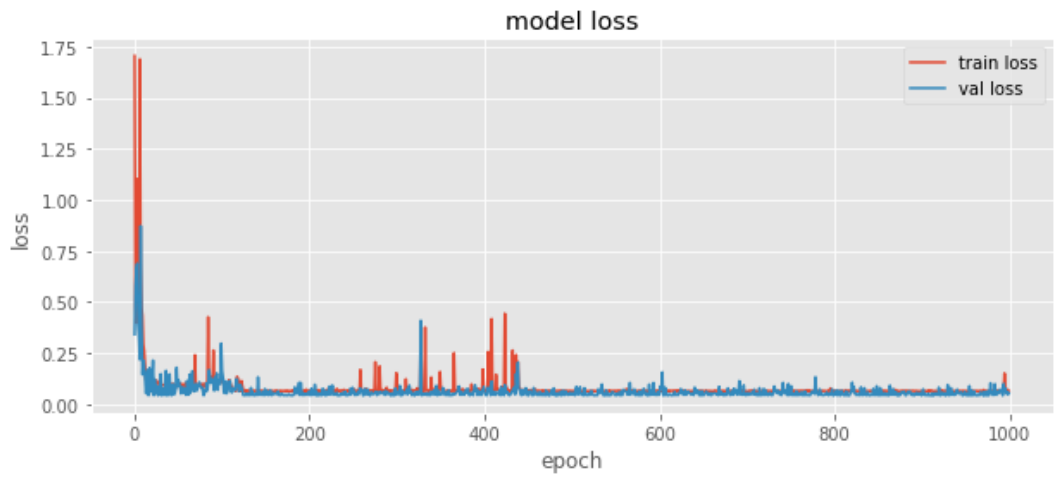

Gambar 2. Grafik Model Loss dengan Nilai Learning Rate 0.1 


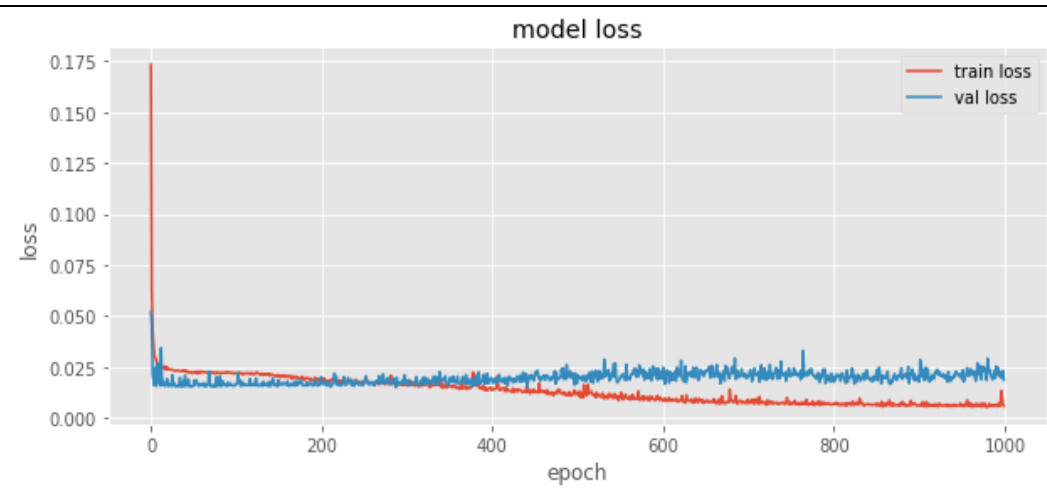

Gambar 3. Grafik Model Loss dengan Nilai Learning Rate 0.01

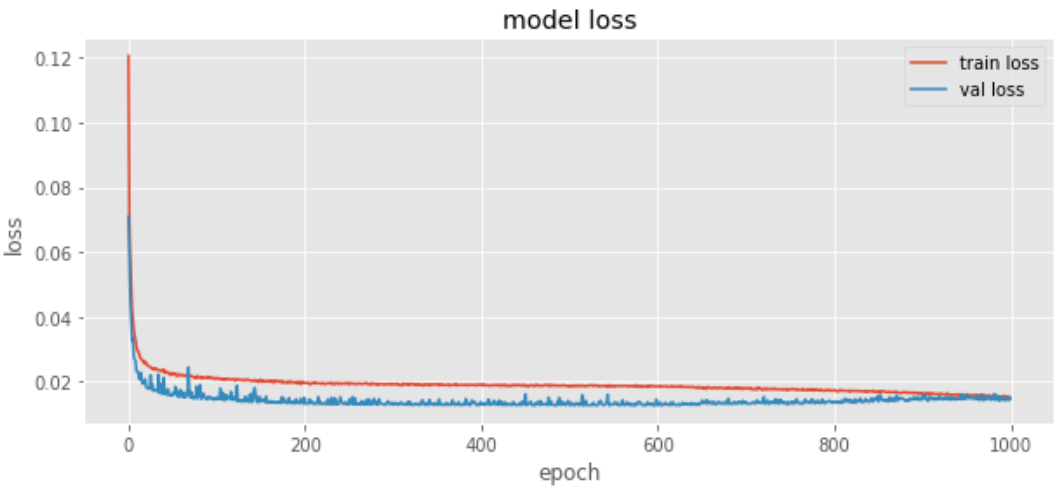

Gambar 4. Grafik Model Loss dengan Nilai Learning Rate 0.001

Pada Gambar 2 dan Gambar 3, model prediksi dengan nilai learning rate 0.1 dan 0.01 terjadi fluktuasi terhadap training loss dan validation loss. Hal tersebut dapat dinyatakan bahwa nilai learning rate terlalu besar bagi model prediksi. Sedangkan pada Gambar 4 dengan nilai learning rate tidak mengalami fluktuasi pada training loss maupun model loss serta tidak mengalami overfitting pada model prediksi. Berdasarkan beberapa pengujian yang dilakukan, berikut merupakan hasil training loss dan validation loss dari model prediksi pada masing-masing nilai learning rate yang dapat dilihat pada Tabel 1.

\begin{tabular}{ccc}
\multicolumn{3}{c}{ Tabel 1. Hasil Pengujian Penentuan Learning Rate } \\
\hline Learning rate & Training loss & Validation loss \\
\hline 0.1 & 0.06619 & 0.05541 \\
0.01 & 0.005956 & 0.018616 \\
0.001 & 0.015063 & 0.014608 \\
\hline
\end{tabular}

Berdasarkan pada Tabel 1, dapat dilihat bahwa nilai training loss dan validation loss pada pengujian learning rate 0.1 paling besar. Sedangkan pada pengujian nilai learning rate 0.01 menghasilkan nilai training loss yang sangat kecil, namun di sisi lain nilai validation loss nya masih besar hal ini menandakan bahwa terjadinya overfitting pada model. Pada pengujian nilai learning rate 0.001 menghasilkan nilai training loss dan validation loss yang sama-sama kecil, hal tersebut dapat dinyatakan nilai learning rate tersebut cocok digunakan pada model prediksi ini. Berdasarkan hasil dari pengujian yang dilakukan, maka nilai learning rate yang digunakan pada model prediksi ini adalah 0.001 .

\subsection{Pengujian Penentuan Hidden Unit}

Pengujian ini dilakukan untuk mendapatkan jumlah hidden unit terbaik pada model prediksi. Jumlah hidden unit yang diujikan pada penelitian ini yaitu 32, 64, 128 dan 256. Penentuan jumlah hidden unit terbaik didasarkan pada nilai rata-rata RMSE terkecil dengan masing-masing jumlah hidden unit diuji menggunakan nilai learning rate 0.001 dan jumlah batch 
size yang berbeda-beda yaitu 2, 4, 8 dan 16. Berikut merupakan hasil dari pengujian penentuan jumlah hidden unit yang dapat dilihat pada Tabel 2, Tabel 3, Tabel 4, dan Tabel 5.

Tabel 2. Hasil RMSE dengan Jumlah Hidden Unit 32

\begin{tabular}{cccc}
\hline $\begin{array}{c}\text { Hidden } \\
\text { unit }\end{array}$ & $\begin{array}{c}\text { Learning } \\
\text { Rate }\end{array}$ & $\begin{array}{c}\text { Batch } \\
\text { size }\end{array}$ & RMSE \\
\hline 32 & 0.001 & 2 & 313.261 \\
32 & 0.001 & 4 & 298.1643 \\
32 & 0.001 & 8 & 326.9122 \\
32 & 0.001 & 16 & 247.3952 \\
\hline \multicolumn{4}{c}{ Rata-rata RMSE : } \\
\hline
\end{tabular}

Tabel 3. Hasil RMSE dengan Jumlah Hidden Unit 64

\begin{tabular}{cccc}
\hline $\begin{array}{c}\text { Hidden } \\
\text { unit }\end{array}$ & $\begin{array}{c}\text { Learning } \\
\text { Rate }\end{array}$ & $\begin{array}{c}\text { Batch } \\
\text { size }\end{array}$ & RMSE \\
\hline 64 & 0.001 & 2 & 353.5218 \\
64 & 0.001 & 4 & 298.7832 \\
64 & 0.001 & 8 & 279.5317 \\
64 & 0.001 & 16 & 274.184 \\
\hline \multicolumn{4}{c}{ Rata-rata RMSE } \\
\hline
\end{tabular}

Tabel 4. Hasil RMSE dengan Jumlah Hidden Unit 128

\begin{tabular}{cccc}
\hline $\begin{array}{c}\text { Hidden } \\
\text { unit }\end{array}$ & $\begin{array}{c}\text { Learning } \\
\text { Rate }\end{array}$ & $\begin{array}{c}\text { Batch } \\
\text { size }\end{array}$ & RMSE \\
\hline 128 & 0.001 & 2 & 280.7765 \\
128 & 0.001 & 4 & 267.1991 \\
128 & 0.001 & 8 & 313.0491 \\
128 & 0.001 & 16 & 353.0937 \\
\hline \multicolumn{4}{c}{ Rata-rata RMSE } \\
\hline
\end{tabular}

Tabel 5. Hasil RMSE dengan Jumlah Hidden Unit 256

\begin{tabular}{cccc}
\hline Hidden & Learning & $\begin{array}{c}\text { Batch } \\
\text { size }\end{array}$ & RMSE \\
unit & Rate & 2 & 337.6409 \\
256 & 0.001 & 4 & 279.5032 \\
256 & 0.001 & 8 & 288.1624 \\
256 & 0.001 & 16 & 304.8415 \\
256 & 0.001 & & 302.537 \\
\hline \multicolumn{4}{c}{ Rata-rata RMSE } \\
\hline
\end{tabular}

Berdasarkan hasil pengujian pada Tabel 2, Tabel 3, Tabel 4, dan Tabel 5, dapat dilihat nilai rata-rata RMSE terkecil terdapat pada jumlah hidden unit sebesar 32 yaitu 296.4333. Sedangkan nilai RMSE terkecil terdapat pada jumlah learning rate 0.001 , hidden unit sebesar 32 dan batch size sebesar 16 dengan menghasilkan RMSE sebesar 247.3952. Berdasarkan hasil rata-rata RMSE pada beberapa pengujian tersebut, dapat dinyatakan bahwa jumlah hidden unit yang digunakan pada penelitian ini yaitu sebesar 32 .

\subsection{Pengujian Penentuan Batch Size}

Pada tahap ini, melakukan pengujian untuk mendapatkan jumlah batch size terbaik pada model prediksi. Jumlah batch size yang diujikan pada penelitian ini yaitu 2, 4, 8 dan 16 . Penentuan pemilihan jumlah batch size terbaik didasarkan pada nilai rata-rata RMSE terkecil yang diuji menggunakan variasi jumlah epoch yang berbeda-beda yaitu 1000, 1500 dan 2000. Berikut merupakan hasil dari pengujian penentuan hidden unit yang dapat dilihat pada Tabel 6 , Tabel 7 , Tabel 8, dan Tabel 9. 
Tabel 6. Hasil RMSE dengan Jumlah Batch Size 2

\begin{tabular}{ccccc}
\hline Batch size & Learning Rate & Hidden Unit & Epoch & RMSE \\
\hline 2 & 0.001 & 16 & 1000 & 313.261 \\
2 & 0.001 & 16 & 1500 & 287.4729 \\
2 & 0.001 & 16 & 2000 & 294.3051 \\
\hline \multicolumn{5}{c}{ Rata-rata RMSE } \\
\hline
\end{tabular}

Tabel 7. Hasil RMSE dengan Jumlah Batch Size 4

\begin{tabular}{ccccc}
\hline Batch size & Learning Rate & Hidden Unit & Epoch & RMSE \\
\hline 4 & 0.001 & 16 & 1000 & 298.1643 \\
4 & 0.001 & 16 & 1500 & 309.8785 \\
4 & 0.001 & 16 & 2000 & 296.8327 \\
\hline \multicolumn{5}{c}{ Rata-rata RMSE } \\
\hline
\end{tabular}

Tabel 8. Hasil RMSE dengan Jumlah Batch Size 8

\begin{tabular}{ccccc}
\hline Batch size & Learning Rate & Hidden Unit & Epoch & RMSE \\
\hline 8 & 0.001 & 16 & 1000 & 326.9122 \\
8 & 0.001 & 16 & 1500 & 309.3132 \\
8 & 0.001 & 16 & 2000 & 344.5636 \\
\hline \multicolumn{5}{c}{ Rata-rata RMSE } \\
\hline
\end{tabular}

Tabel 9. Hasil RMSE dengan Jumlah Batch Size 16

\begin{tabular}{ccccc}
\hline Batch size & Learning Rate & Hidden Unit & Epoch & RMSE \\
\hline 16 & 0.001 & 16 & 1000 & 247.3952 \\
16 & 0.001 & 16 & 1500 & 268.9501 \\
16 & 0.001 & 16 & 2000 & 297.2386 \\
\hline \multicolumn{5}{c}{ Rata-rata RMSE } \\
\hline
\end{tabular}

Berdasarkan hasil pengujian pada Tabel 6, Tabel 7, Tabel 8, dan Tabel 9, dapat dilihat nilai rata-rata RMSE terkecil terdapat pada jumlah batch size sebesar 16 yaitu 203.396. Sedangkan nilai RMSE terkecil terdapat pada komposisi hyperparamater learning rate sebesar 0.001 , hidden unit sejumlah 32, batch sejumlah 16 dan epoch sejumlah 1000 dengan menghasilkan RMSE sebesar 247.3952. Berdasarkan hasil rata-rata RMSE pada beberapa pengujian tersebut, dapat dinyatakan bahwa jumlah batch size yang digunakan pada penelitian ini yaitu sebesar 16 .

\subsection{Pengujian Penentuan Epoch dan Partisi Data}

Pengujian pada tahap ini dilakukan untuk mengetahui jumlah epoch dan partisi data yang terbaik pada model prediksi. Jumlah epoch yang diujikan pada penelitian ini yaitu 2, 4, 8 dan 16 sedangkan partisi data yang diujikan adalah data latih $60 \%$, data validasi $10 \%$ dan data uji $30 \%$, data latih $70 \%$, data validasi $10 \%$ dan data uji $20 \%$ dan data latih $80 \%$, data validasi $10 \%$ dan data uji $10 \%$. Penentuan pemilihan jumlah epoch dan partisi data terbaik didasarkan pada nilai RMSE terkecil. Berikut merupakan hasil dari pengujian penentuan hidden unit yang dapat dilihat pada Tabel 10, Tabel 11, dan Tabel 12.

Tabel 10. Hasil RMSE dengan Epoch 1000 dan Partisi Data Bervariasi

\begin{tabular}{cccccc}
\hline Epoch & Partisi Data & $\begin{array}{c}\text { Learning } \\
\text { Rate }\end{array}$ & $\begin{array}{c}\text { Hidden } \\
\text { Unit }\end{array}$ & Batch size & RMSE \\
\hline 1000 & $\begin{array}{c}\text { Data latih }=60 \% \\
\text { Data validasi }=10 \% \\
\text { Data uji }=30 \% \\
\text { Data latih }=70 \%\end{array}$ & 0.001 & 32 & 16 & 307.419 \\
$\begin{array}{c}\text { Data validasi }=10 \% \\
\text { Data } \text { uji }=20 \% \\
\text { Data latih }=80 \% \\
\text { Data validasi }=10 \% \\
\text { Data uji } 10 \%\end{array}$ & 0.001 & 32 & 16 & 247.3952 \\
\hline & 0.001 & 32 & 16 & 260.659 \\
\hline
\end{tabular}




\begin{tabular}{|c|c|c|c|c|c|}
\hline Epoch & Partisi Data & $\begin{array}{l}\text { Learning } \\
\text { Rate }\end{array}$ & $\begin{array}{l}\text { Hidden } \\
\text { Unit }\end{array}$ & Batch size & RMSE \\
\hline 1500 & $\begin{array}{c}\text { Data latih }=60 \% \\
\text { Data validasi }=10 \% \\
\text { Data uji }=30 \% \\
\text { Data }\end{array}$ & 0.001 & 32 & 16 & 314.4545 \\
\hline 1500 & $\begin{array}{c}\text { Data validasi }=10 \% \\
\text { Data uji=20\% } \\
\text { Data latih }=80 \%\end{array}$ & 0.001 & 32 & 16 & 268.9501 \\
\hline 1500 & $\begin{array}{c}\text { Data validasi }=10 \% \\
\text { Data uji }=10 \%\end{array}$ & 0.001 & 32 & 16 & 324.8828 \\
\hline
\end{tabular}

Tabel 12. Hasil RMSE dengan Epoch 2000 dan Partisi Data Bervariasi

\begin{tabular}{cccccc}
\hline Epoch & Partisi Data & $\begin{array}{c}\text { Learning } \\
\text { Rate }\end{array}$ & $\begin{array}{c}\text { Hidden } \\
\text { Unit }\end{array}$ & Batch size & RMSE \\
\hline 2000 & $\begin{array}{c}\text { Data latih }=60 \% \\
\text { Data validasi }=10 \% \\
\text { Data uji }=30 \%\end{array}$ & 0.001 & 32 & 16 & 352.6851 \\
$\begin{array}{c}\text { Data latih }=70 \% \\
\text { Data validasi }=10 \% \\
\text { Data uji }=20 \% \\
\text { Data latih }=80 \% \\
\text { Data validasi }=10 \% \\
\text { Data uji }=10 \%\end{array}$ & 0.001 & 32 & 16 & 297.2386 \\
\hline & 0.001 & 32 & 16 & 358.3605 \\
\hline
\end{tabular}

Berdasarkan hasil pengujian pada Tabel 10, Tabel 11, dan Tabel 12, dapat ditetapkan hyperparameter terbaik dari model prediksi pada penelitian ini ialah dengan komposisi sebagai berikut learning rate sebesar 0.001 , hidden unit sejumlah 32 , batch sejumlah 16 , epoch sejumlah 1000 dan partisi data dengan komposisi data latih sebesar $70 \%$, data validasi sebesar $10 \%$ dan data uji sebesar $20 \%$. Hasil RMSE yang dihasilkan oleh model prediksi dengan hyperparameter tersebut adalah sebesar 247.3952. Berikut merupakan grafik model loss yang dihasilkan oleh model prediksi pada penelitian ini yang dapat dilihat pada Gambar 5.

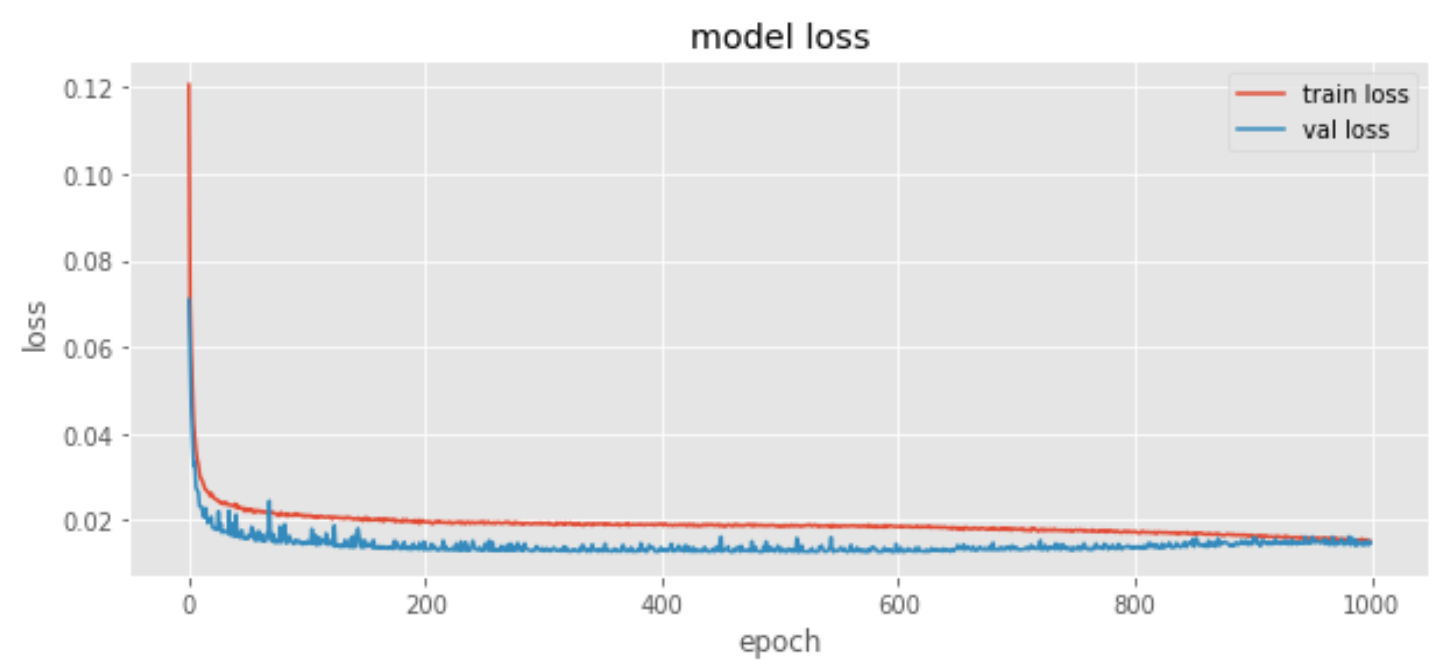

Gambar 5. Grafik Model Loss dari Model Prediksi Permintaan Kargo

Berdasarkan Gambar 5, grafik yang dihasilkan sangat baik tidak terdapat fluktuasi yang signifikan serta tidak mengalami overfitting pada model prediksi. Berikut merupakan sampel hasil dan grafik perbandingan data aktual dan data prediksi yang dapat dilihat pada Tabel 13 dan Gambar 6. 
Tabel 13. Sampel Hasil Perbandingan Data Aktual dan Data Prediksi

\begin{tabular}{cc}
\hline Data & $\begin{array}{c}\text { Data } \\
\text { Aktual }\end{array}$ \\
Prediksi \\
\hline 444.5 & 459.865814 \\
388.5 & 455.405029 \\
387.0 & 369.029907 \\
361.0 & 407.359467 \\
484.5 & 494.883942 \\
$\ldots$ & $\ldots$ \\
546.0 & 637.285767 \\
1099.0 & 525.613159 \\
889.4 & 672.127136 \\
776.0 & 583.760986 \\
558.0 & 428.463043 \\
\hline
\end{tabular}

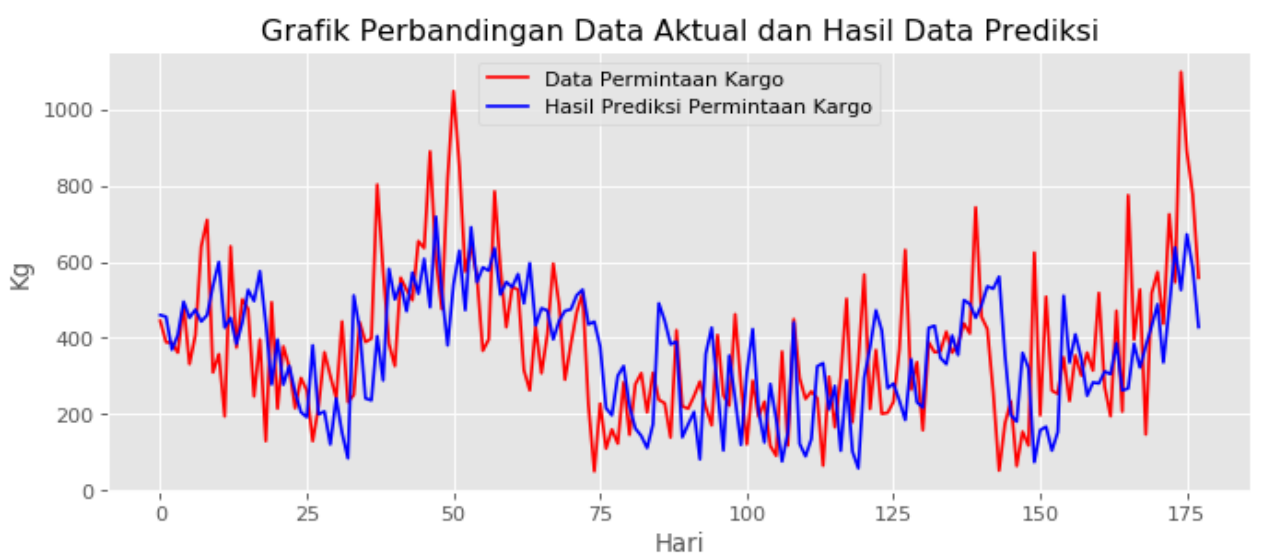

Gambar 6. Grafik Perbandingan Data Aktual dan Hasil Data Prediksi

Dapat dilihat pada Tabel 13 dan Gambar 6, selisih data aktual dan data prediksi tidak terlalu besar. Dapat dilihat grafik tersebut bahwa pergerakan data hasil prediksi dapat mengikut pola pergerakan data aktual. Namun terdapat dibeberapa titik misalnya dititik puncak, hasil prediksi GRU masih belum maksimal mengikuti pergerakan data aktual tersebut

\section{Kesimpulan}

Berdasarkan perancangan, implementasi dan hasil dalam penelitian ini, penentuan hyperparameter terbaik pada model prediksi dilakukan dengan melakukan beberapa pengujian berdasarkan nilai hyperparameter yang ditentukkan. hyperparameter terbaik dari model prediksi pada penelitian ini adalah dengan komposisi : learning rate sebesar 0.001, hidden unit sejumlah 32, batch sejumlah 16, epoch sejumlah 1000 dan partisi data dengan komposisi data latih $70 \%$, data validasi $10 \%$ dan data uji $20 \%$. Hasil nilai kesalahan (error) RMSE dari model prediksi dengan menggunakan hyperparameter terbaik adalah sebesar 247.3952.

Berdasarkan hasil tersebut, model prediksi GRU cukup baik dalam melakukan prediksi permintaan kargo CSC Tangerang City, namun terdapat beberapa hasil prediksi metode GRU yang masih belum maksimal mendekati nilai aktual misalnya pada nilai aktual yang berada di titik puncak. Hal tersebut dikarenakan data yang digunakan masih sedikit serta nilai variansi data yang besar, sehingga model GRU belum maksimal dalam melakukan prediksi. Adapun beberapa hal yang dapat dilakukan dalam mengembangkan dan melakukan penelitian selanjutnya. Berikut merupakan beberapa saran dari penulis untuk penelitian selanjutnya :

1. Dapat menggunakan metode Deep Learning lainnya seperti LSTM, CNN dan lain-lain.

2. Menambahkan pengujian hyperparameter yang lainnya, seperti penentuan nilai lag, algoritma optimisasi (optimizers) yang digunakan dan lain-lain.

3. Menggunakan jumlah data yang lebih banyak, dikarenakan jumlah data berpengaruh dalam prediksi menggunakan metode GRU atau Deep Learning. 


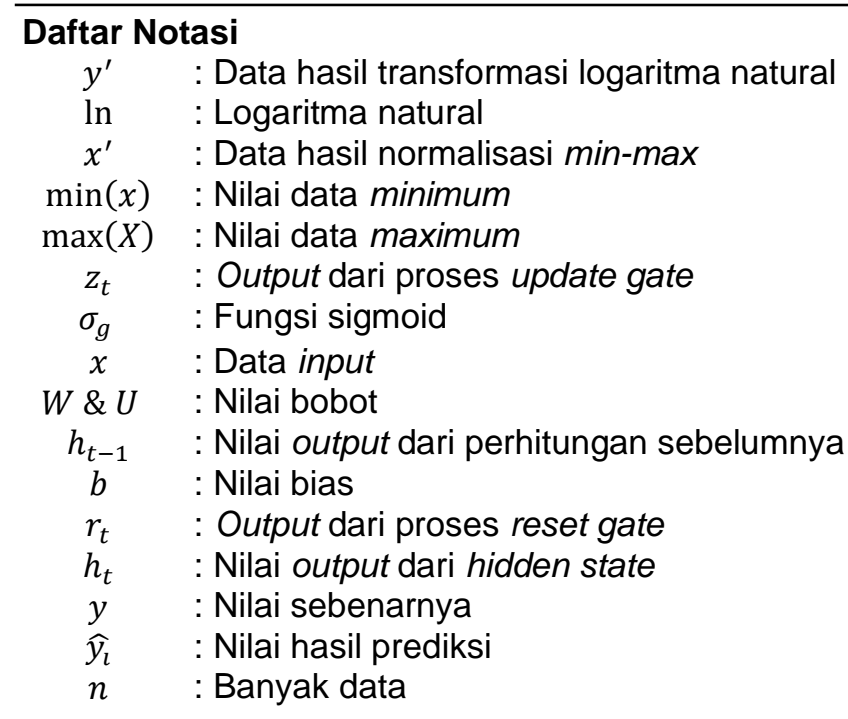

\section{Referensi}

[1] A. Gusfadilah, B. D. Setiawan, and B. Rahayudi, "Implementasi Metode Exponential Smoothing Untuk Prediksi Bobot Kargo," J. Pengemb. Teknol. Inf. dan IImu Komput., vol. 3, no. 2, pp. 1875-1882, 2019.

[2] G. Baxter and P. Srisaeng, "The Use of an Artificial Neural Network to Predict Australia'S Export Air Cargo Demand," Int. J. Traffic Transp. Eng., vol. 8, no. 1, pp. 15-30, 2018.

[3] K. Uyar, "Long Term Dry Cargo Freight Rates Forecasting by Using Recurrent Fuzzy Neural Networks," in 12th International Conference on Application of Fuzzy Systems and Soft Computing, 2016, pp. 642-647.

[4] R. Fu, Z. Zhang, and L. Li, "Using LSTM and GRU Neural Network Methods for Traffic Flow Prediction," in 31st Youth Academic Annual Conference of Chinese Association of Automation, 2016, pp. 5-9.

[5] Aji, Hendridha Wisnu. 2019. Skripsi. Prediksi Harga Bitcoin dengan Menggunakan Metode Gated Recurrent Unit (GRU). Fakultas Matematika dan Ilmu Pengetahuan Alam. Jurusan IImu Komputer. Universitas Lambung Mangkurat. Banjarbaru.

[6] K. Cho, D. Bahdanau, and F. Bougares, "Learning Phrase Representations using RNN Encoder - Decoder for Statistical Machine Translation," in Conference on Empirical Methods in Natural Language Processing, 2014, pp. 1724-1734.

[7] J. Chung, "Empirical Evaluation of Gated Recurrent Neural Networks on Sequence Modeling," in NIPS 2014 Workshop on Deep Learning, 2014, pp. 1-9.

[8] M. O. Rahman, S. Hossain, T. Junaid, and S. A. Forhad, "Predicting Prices of Stock Market using Gated Recurrent Units (GRUs) Neural Networks," IJCSNS Int. J. Comput. Sci. Netw. Secur., vol. 19, no. 1, pp. 213-222, 2019.

[9] Hasihi, Amalia Erman. 2019. Skripsi. Forecast Permintaan Kargo Udara dari Makassar ke Wilayah Papua Menggunakan Metode Double Constraint Gravity Model (DCGR). Jurusan Manajemen. Sekolah Tinggi Ilmu Ekonomi Nobel Indonesia. Makassar.

[10] Rizki, Muhammad. 2019. Skripsi. Implementasi Deep Learning Menggunakan Arsitektur Long Short Term Memory (LSTM) untuk Prediksi Curah Hujan Kota Malang. Fakultas Teknik. Jurusan Teknik Informatika. Universitas Muhammadiyah Malang. Malang. 